\title{
ANALISIS EFISIENSI PEMAKAINAN BAHAN BAKAR MESIN INDUK KAPAL PURSE SEINER DI PELABUHAN PENDARATAN NUSANTARA PEKALONGAN
}

\author{
Solichin Djazuli Sa'id \\ Program Studi Diploma III Teknik Perkapalan \\ Fakultas Teknik Universitas Diponegoro
}

\begin{abstract}
Solichin Djazuli Sa'id, in this paper explain that fuel consumption for each vessel were variations depending on the size of ships, ships with a larger size will require more fuel for each mile distance the ship with a GT 101 for a distance of 1 mile with a speed of 6 knots require diesel fuel (dieselfue oil ) 6.24 liter, GT 1991: 6.06 liter, GT 80: 5.69 liter, GT 71: 5.13 liter, GT 61;4.74 liter and most economical is the GT 45 is only 3.30 liters per milnya

The lowest operating costs of fishing vessels is to measure 45GT, 101GT highest. Operational Cost $(\mathrm{OC})$ is the most economical ship with size 45 GT (Modern I).Operational costs are dominating the supply of fuel (diesel) $44 \%$.

Profit rate (profit rate) obtained by vessels of 45 GT (Modern I) has a rate of returnabove 15\%, the highest in comparison with vessels of above.
\end{abstract}

Keywords: Fuel consumption, operating costs

\section{PENDAHULUAN}

Masyarakat nelayan di Jawa Tengah dirasakan cukup terpuruk, terutama nasib para nelayan yang mengandalkan alat dan armada terbatas, kurang dari 10 grosstone/GT. Hal tersebut disebabkan oleh hasil produksi tangkapan menurun akibat usaha tangkap yang melebihi kapasitas lestari (overfishing) dan mengganggu proses pemulihan stok ikan (renewable), rusaknya ekosistem, diikuti pula cuaca yang tidak menentu, berbagai faktor alam yang mempengaruhi antara lain, gelombang, angin serta arus yang sulit diprediksi sebagai gejala pemanasan global (global warming).

Perjuangan dan pengorbanan masyarakat nelayan untuk menangkap ikan di laut tidak sebanding dengan hasil tangkapan dan pendapatan dari hasil penjualan ikan yang diperoleh bahkan cenderung merugi. Hal ini tentunya akan mempengaruhi kesejahteraan nelayan. Dalam konteks yang lebih jauh kesejahteraan keluarga nelayan pun akan terkena imbasnya.

Sebagai sebuah profesi yang menjadi tradisi masyarakat pesisir tradisional, nelayan senantiasa menghadapi lingkaran permasalahan yang cukup pelik. Karakteristik sumber daya perikanan laut milik bersama (common property), yang disalahartikan semua pihak berhak memanfaatkan atau bisa juga berarti tidak ada satu pihak pun yang memiliki, yang memunculkan rezim open access turut menambah keterpurukan nelayan. Kelompok profesi inilah yang senantiasa menghadapi tantangan maupun ancaman dari laut sekaligus dari darat.

\section{Kondisi Perikanan Tangkap di Jawa Tengah}

Masyarakat nelayan di Jawa Tengah bergerak seiring dengan perkembangan jumlah armada perikanan laut. Nelayan sebagai pelaku utama kegiatan usaha penangkapan ikan di Jawa Tengah berjumlah 168.113 orang (DPK Jateng, 2005), sedangkan Provinsi Jawa Tengah mempunyai wilayah seluas 32.284.268 Km2 atau seluas 23,97 \% dari luas wilayah Pulau Jawa, terletak pada koordinat antara $6^{\circ} 30^{\prime}-9^{\circ} 30^{\prime}$ LS dan antara $108^{\circ} 30^{\prime}-111^{\circ} 30^{\prime}$ BT.

Nelayan beroperasi di se panjang garis pantai yang dimiliki Jawa Tengah yaitu 791,764 Km yang terdiri atas Pantai Utara sepanjang 502, $64 \mathrm{Km}$ dan Pantai Selatan sepanjang 289,07 Km. Selain itu, Jawa Tengah mempunyai 34 pulau-pulau kecil.

Di sepanjang pantai utara Jawa Tengah terletak beberapa kota/kabupaten dari bagian timur hingga barat adalah Kabupaten Rembang, Pati, Jepara, Demak, Kota Semarang, Kabupaten Kendal, Batang, Kota Pekalongan, Kabupaten Pekalongan, Pemalang, Tegal, Kota Tegal, dan Kabupaten Brebes. Di bagian selatan, terdiri dari empat kabupaten yaitu Wonogiri, Purworejo, Kebumen, dan Cilacap.

Perikanan tangkap Jawa Tengah yang terdiri dari perikanan laut dan perikanan di perairan pedalaman mempunyai potensi untuk dikembangkan. Potensi perikanan laut yang tersebar di perairan Jawa Tengah sekitar 1.873.530 ton/tahun meliputi Laut Jawa sekitar 796.640 ton/tahun dan Samudera Indonesia sekitar 1.076 .890 ton/tahun. Sedangkan perairan kedalaman mempunyai luas perairan yang dapat dikembangkan untuk kegiatan perikanan. Luas perairan pedalaman Jawa Tengah mempunyai luas total 43.292,30 Ha yang terdiri dari sungai 15.391,90 Ha, waduk 23.016 Ha, rawa 3.514 Ha, danau/cekdam 1.370,40 Ha.

Beberapa jenis unit alat tangkap digunakan oleh para nelayan Jawa Tengah adalah pukat tarik, pukat kantong, pukat cincin, jaring insang, jaring angkat, pancing, alat pengumpul, dan alat tangkap lainnya dengan jumlah total alat tangkap pada tahun 
$2005 \pm 39.045$ unit. Armada penangkapan yang beroperasi di perairan Jawa Tengah \pm 26.597 buah yang terdiri dari perahu tanpa perahu motor, motor tempel, dan kapal motor.

Hasil perikanan tangkap di Jawa Tengah didominasi oleh sumberdaya ikan hasil tangkapan dari laut dibanding perairan pedalaman (danau, waduk, rawa, dan sebagainya). Potensi tangkap sumberdaya ikan yang tersebar di perairan Jawa Tengah sekitar 1.873 .530 ton/tahun meliputi Laut Jawa sekitar 796.640 ton/tahun dan Samudera Indonesia sekitar 1.076.890 ton/tahun, sedangkan armada perikanan laut pada tahun 2005 mencapai 18.790 unit, terdiri dari berbagai ukuran dari 5 - 100 grosstone (GT) .

Produksi penangkapan ikan di laut masyarakat nelayan Jawa Tengah, sudah terindikasi menurun berdasarkan hasil laporan Komisi Stock Assesment Pusat untuk perairan Laut Jawa termasuk WPP (Wilayah Pengelolaan Perikanan ) III meliputi perairan Jawa Barat, Jawa Timur, Kalimantan Selatan dan sebagian Kalimantan Timur. Terdapat penurunan sebesar 21,19\%, dari 244.389,5 ton pada tahun 2004 menjadi 192.586,5 ton pada tahun 2005. Hal tersebut diduga sebagai dampak hasil produksi tangkapnya yang telah mencapai $132 \%$ dari potensi lestari yang ada dan status kawasan tersebut sudah dinyatakan overfishing. Indikatornya adalah hasil tangkapan yang diperoleh menunjukkan ukuran ikannya kecil, waktu operasi penangkapan lebih lama yang diperlukan nelayan menangkap ikan dan jauhnya daerah tangkapan ( fishing ground) serta sedikitnya trip (beroperasinya armada penangkapan) selama satu tahun.

Pada tabel 1 tersebut dapat diinformasikan bahwa sebagian besar armada yang digunakan oleh nelayan Jawa Tengah adalah armada ukuran $0-5$ GT termasuk di dalamnya motor tempel.

Berdasar klasifikasi tentang besaran kapal di Jawa Tengah dan otoritas perizinannya :

- Armada ukuran > 30 GT dengan daerah operasionalnya lebih dari 12 mil untuk perizinannya ditangani oleh Departemen Kelautan dan Perikanan RI.

- Armada ukuran 30 - 10 GT daerah operasionalnya di sekitar 12 mil. Dokumen perizinannya dikelola oleh Dinas Perikanan dan Kelautan Propinsi.

- Armada ukuran 10 - 5 GT daerah operasionalnya 6 mil pengelolaan perizinannya dilakukan oleh Kabupaten/Kota.

Berdasar status kepemilikan armada dan operasionalnya dapat dijelaskan bahwa :

- Armada ukuran > 30 GT sebagian besar kapalkapal tersebut dimiliki oleh para pengusaha dan rata-rata kepemilikannya setiap pengusaha di atas 2 kapal. Daerah operasionalnya lebih dari 12 mil sehingga sangat berhubungan dengan daerah operasi teritorial, sehingga berbatasan dengan provinsi yang lain. Lama operasi penangkapan berkisar 3 minggu hingga 1 bulan,

Tabel 1. Prosentase Armada Penangkapan yang Beroperasi di Jalur Penangkapan dan Jenis Alat

\begin{tabular}{|c|c|c|c|c|c|}
\hline $\begin{array}{c}\text { Jarak dari } \\
\text { Pantai (Mil) }\end{array}$ & $\begin{array}{c}\text { Ukuran } \\
\text { (GT) }\end{array}$ & $\begin{array}{l}\text { Jumlah } \\
\text { Armada }\end{array}$ & $\begin{array}{c}\text { Prosentase } \\
(\%)\end{array}$ & $\begin{array}{c}\text { Jalur } \\
\text { Tangkap }\end{array}$ & Jenis Alat Tangkap \\
\hline $0-3$ & $\begin{array}{c}0-5(\text { dan } \\
\text { Motor } \\
\text { Tempel) }\end{array}$ & 16.119 & 85,78 & $\mathrm{IA}+\mathrm{IB}$ & $\begin{array}{l}\text { Trammel net, jaring } \\
\text { loang, pejer, } \\
\text { rajungan, ciker, } \\
\text { bundes, dogol, bagan, } \\
\text { payang, dan gill net } \\
\text { monofilament }\end{array}$ \\
\hline $3-6$ & $5-10$ & 534 & 2,84 & IB & $\begin{array}{l}\text { Payang, lampara, gill } \\
\text { net, gill net } \\
\text { millenium, gill net } \\
\text { monofilament }\end{array}$ \\
\hline $6-12$ & $10-30$ & 1.243 & 6,62 & II & $\begin{array}{l}\text { Prawe, gill net, mini } \\
\text { purse sein, bubu }\end{array}$ \\
\hline$>12$ & $>30$ & 894 & 4,76 & $\mathrm{III}+\mathrm{ZEE}$ & $\begin{array}{l}\text { Mini purse sein, gill } \\
\text { net cakalang, } \\
\text { cantrang besar, } \\
\text { prawe, purse sein, } \\
\text { long line. }\end{array}$ \\
\hline
\end{tabular}

Sumber : Buku Statistik Perikanan Tangkap Jawa Tengah, 2005 
SDM para pengusaha serta tingkat pengetahuan mengenai kepemilikan dokumen kapal perikanan pada umumnya telah mengetahui dengan jelas serta sanksi yang akan dikenakan. Sehubungan dengan pemahaman tersebut maka sebagian besar kapal-kapal ikan di atas 30 GT telah mempunyai dokumen kapal perikanan dengan baik. Sedangkan alat tangkap yang digunakan adalah purse sein dengan ratarata $\mathrm{ABK}$ mencapai 40 orang setiap kapal.

- Armada ukuran 30 - 10 GT dimiliki oleh pengusaha dan biasanya jumlah kepemilikan setiap orang lebih dari satu. Daerah operasionalnya sekitar 12 mil. Dengan rata-rata lama operasi di laut 2-3 minggu. Tingkat pengetahuan tentang dokumen kapal perikanan cukup rendah. Dengan indikator yang mempunyai izin kapal perikanan berkisar 20\% dari armada yang ada. Alat tangkap yang digunakan minipursesein, cantrang, serta mini longline.

- Armada ukuran 10 - 5 GT dimiliki oleh nelayan sendiri . Operasional penangkapan di bawah 12 mil. Lama operasionalnya 1 - 5 hari. Tingkat pengetahuan tentang dokumen kapal perikanan masih sangat rendah. Hal ini terlihat yang memiliki izin perikanan atau surat keterangan dari instansi penerbit dokumen kapal perikanan relatif tidak ada. Hal ini mengakibatkan banyak armada ukuran ini yang ditangkap oleh instansi pengawas. Pada umumnya, alat tangkap yang digunakan trammel net, gill net.

\section{Permasalahan Masyarakat Nelayan}

Salah satu masalah saat masyarakat nelayan melakukan penangkapan ikan di laut adalah terus meningkatnya biaya operasional waktu melaut akibat terus naiknya harga bahan bakar minyak yang banyak dikonsumsi untuk menuju fishing ground yang semakin jauh dari pantai asal nelayan.

Oleh sebab itu perlu dilakukan kajian terhadap pemakaian bahan bakar pada kapal yang dihasilkan dengan pemakaian mesin induk yang sama pada ukuran kapal berbeda khususnya armada kapal purse seine di Pekalongan. Kemudian menganalisa tingkat konsumsi bahan bakar yang ekonomis dari kegiatan operasional penangkapan ikan, untuk masing-masing kapal diperbandingkan pemakaian bahan bakar per mil dan kecepatan yang di peroleh serta tingkat pendapatan untuk satu periode tangkap dengan hasil tangkap dan harga ikan yang sama. Hal ini dilakukan untuk memperoleh gambaran kapal ukuran GT berapa dengan mesin yang sama akan menghasilkan persentase keuntungan lebih tingi.

\section{MATERI DAN METODE PENELITIAN} Materi

Materi penelitian adalah kapal purse seine di PPN Pekalongan berjumlah 6 unit kapal dengan ukuran 45 GT sampai dengan 101 GT dengan mesin induk Nisan RD.8-300 HP.

Tabel 2.Data 6 kapal purse sein Pekalongan hasil survey, 2009

\begin{tabular}{|c|c|c|c|c|c|c|c|c|c|c|}
\hline \multirow[b]{3}{*}{ No. } & \multirow[b]{3}{*}{ Nama Kapal } & \multirow[b]{2}{*}{ GT } & \multicolumn{3}{|c|}{ main dimension } & \multicolumn{2}{|c|}{ Mesin } & \multirow{2}{*}{$\begin{array}{c}\begin{array}{c}\text { Kecepatan } \\
\text { service }\end{array} \\
\end{array}$} & \multirow[b]{2}{*}{$\mathrm{ABK}$} & \multirow[b]{2}{*}{ Trip } \\
\hline & & & $\mathrm{L}$ & B & D & Induk & Genset & & & \\
\hline & & \begin{tabular}{|l} 
(tonnages) \\
\end{tabular} & $(\mathrm{m})$ & (m) & (m) & (PK) & $(\mathrm{kW})$ & (knots) & (orang) & (hari) \\
\hline 1 & & 3 & 4 & 5 & 6 & 7 & 8 & 9 & 10 & 11 \\
\hline 1 & Modern I & 45 & 18.03 & 6.35 & 2.00 & 300 & 30 & 6.00 & 23 & 100 \\
\hline 2 & $\begin{array}{l}\text { Cherly Prima } \\
\text { Utama }\end{array}$ & 61 & 22.71 & 6.65 & 2.10 & 300 & 30 & 6.00 & 35 & 110 \\
\hline 3 & Yuie Jaya & 71 & 21.46 & 6.91 & 2.20 & 300 & 30 & 6.00 & 35 & 110 \\
\hline 4 & $\begin{array}{l}\text { Bintang Mas } \\
\text { Berlian }\end{array}$ & 80 & 23.18 & 6.85 & 2.11 & 300 & 30 & 6.00 & 35 & 93 \\
\hline 5 & $\begin{array}{l}\text { Baruna Batara } \\
\text { Sakti }\end{array}$ & 91 & 23.96 & 7.02 & 2.30 & 300 & 30 & 6.00 & 35 & 110 \\
\hline 6 & Bintang Rejeki & 101 & 26.38 & 7.70 & 2.49 & 300 & 30 & 6.00 & 35 & 103 \\
\hline
\end{tabular}

\section{Metode}

Metode yang digunakan dalam penelitian ini adalah metode survey, yaitu studi pengamatan langsung dilapangan dan studi literatur berdasarkan hasil-hasil penelitian sebelumnya guna pengumpulan data dan informasi untuk menjawab permasalahanpermasalahan yang ada dalam penelitian ini.

\section{Observasi Data Lapangan}

Setelah permasalahan yang akan diteliti teridentifikasi, maka dilanjutkan dengan proses pengumpulan data. Data primer diperoleh dengan metode survey, data yang didapat secara langsung dilapangan dan dengan proses interaksi (tanyajawab) dengan nakhoda dan pemilik kapal meliputi identifikasi dan pengukuran terhadap demensi kapal, GT, spesifikasi tenaga mesin penggerak utama (main engine) dan kecepatan kapal 6 (enam) sampel kapal purse seine dengan ukuran 45GT, 61GT, 71GT, 80GT, 91GT dan 101GT, menggunakan daya (HP) mesin induk (Nisan RD8, 300 HP). Data sekunder diperoleh dari data statistik yang dikeluarkan oleh instansi terkait, antara lain : Dinas Perikanan dan Kelautan Kota Pekalongan, Pelabuhan Perikanan Nusantara Pekalongan, dan Koperasi Makaryo Mino berupa produksi hasil tangkapan.

\section{Analisis Data}

Analisa data dilakukan dengan dua tahapan yaitu analisa regresi dan analisa efisiensi. Analisa regresi bertujuan untuk mengkaji besarnya pengaruh kecepatan kapal terhadap pemakaian bahan bakar mesin dan dimensi kapal. Hasil dari analisa tersebut dapat dijadikan dasar untuk mencari pola operasi penangkapan yang lebih efisien diperairan Pekalongan. Analisa data dilakukan dengan menggunakan software microsoft exel untuk analisa regresi. 


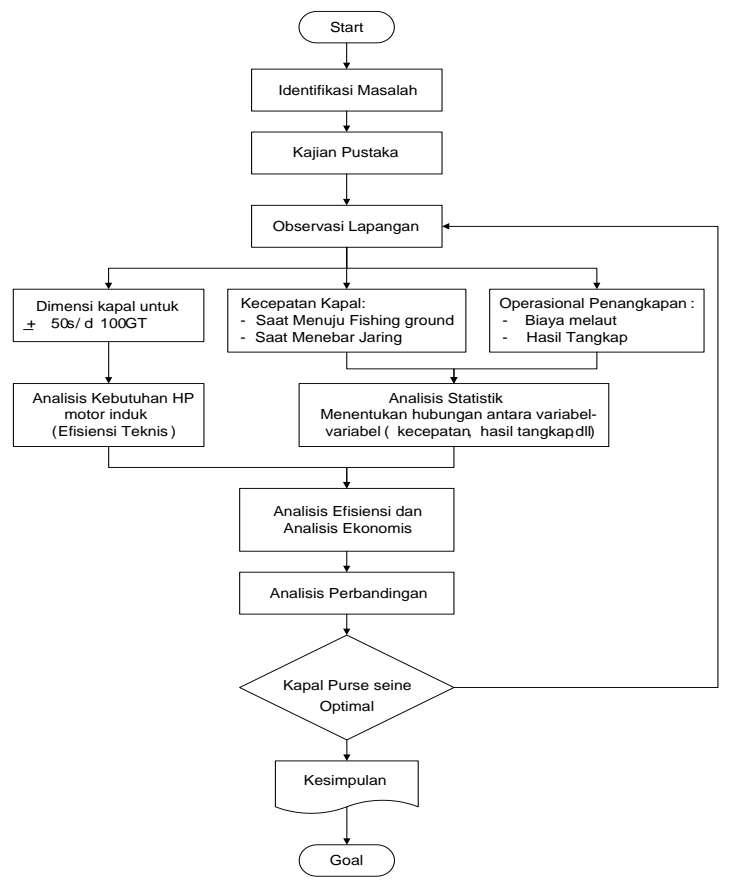

Gambar 1. Diagram alir penelitian

\section{ANALISIS DAN PEMBAHASAN}

\section{Konsumsi Bahan Bakar}

Konsumsi bahan bakar yang di gunakan oleh mesin induk berdasarkan hasil pengambilan data konsumsi bahan bakar di lapangan: dengan cara membuat tangki ukur bahan bakar untuk operasi selama $1 / 2$ sampai 1 jam berlayar (sea trial). Kebutuhan bahan bakar untuk masing-masing kapal dengan GT yang berbeda namun menggunakan Mesin dengan spesifikasi sama yaitu Nissan RD8, 300 HP adalah sebagai berikut; (notes: The density of petroleum diesel is about $0.85 \mathrm{~kg} / \mathrm{liter}$ (7.09 lb/US gal)).

Kebutuhan BBM (solar) untuk tiap kenaikan ukuran kapal (GT) mesin induk :

$B B M=a+b x+c x^{2}$ (liter/jam)
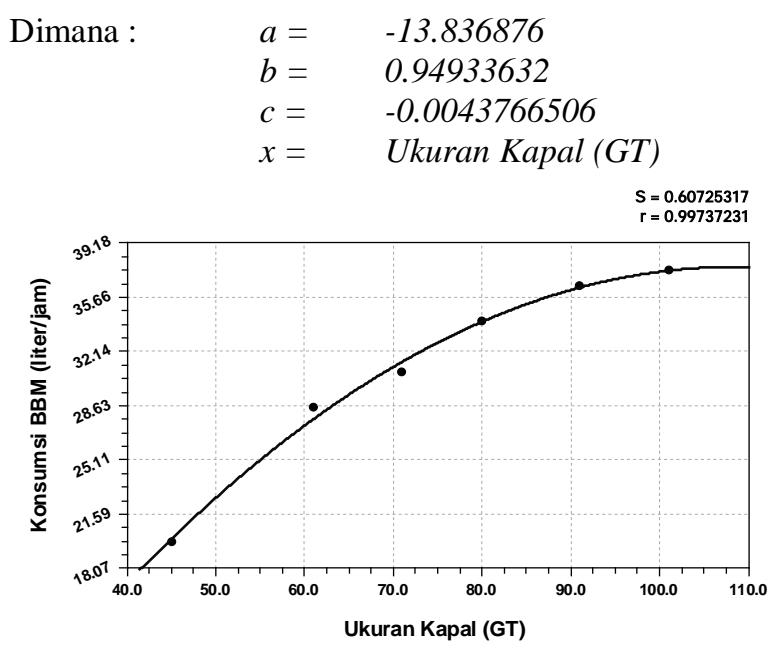

Gambar 2. Konsumsi BBM dengan Ukuran Kapal (GT) kecepatan 6 knots.

Pemakaian bahan bakar sejalan dengan kebutuhan daya mesin, semakin tinggi penggunaan daya mesin maka konsumsi bahan bakar akan meningkat, jika diperhatikan kapal dengan daya mesin yang sama namun jumlah pemakaian bahan bakar berbeda dengan kecepatan yang dihasilkan sama yaitu dengan kecepatan 6 knots (dalam penelitian ini kecepatan yang dipakai untuk tiap kapal sama) dan dapat menempuh jarak 6 mil sehingga konsumsi bahan bakar untuk masing-masing kapal seperti pada gambar 3 .

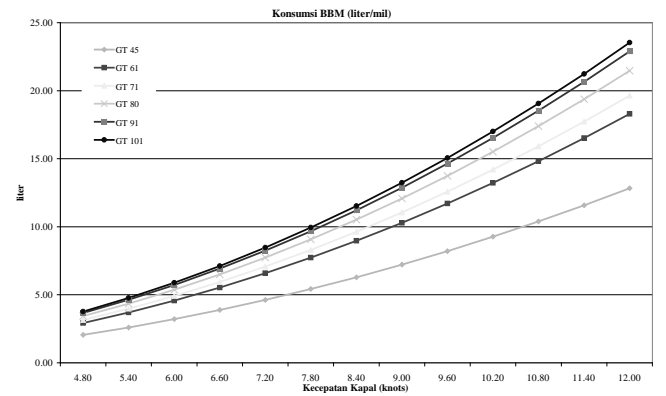

Gambar 3. Konsumsi BBM liter/mil

Tabel.3. Konsumsi bahan bakar (solar)

\begin{tabular}{ccccccc}
\hline \multirow{2}{*}{ Kecepatan } & \multicolumn{7}{c}{$\begin{array}{c}\text { Konsumsi Bahan Bakar Liter Tiap Jam } \\
\text { (Hasil Percobaan, sea trial) }\end{array}$} \\
\hline \multirow{2}{*}{ knots } & $\begin{array}{c}\text { Modern I } \\
\text { GT 45 }\end{array}$ & $\begin{array}{c}\text { CP Utama } \\
\text { GT 61 }\end{array}$ & $\begin{array}{c}\text { Yuiee Jaya } \\
\text { Gt 71 }\end{array}$ & $\begin{array}{c}\text { Bintang M B } \\
\text { GT 81 }\end{array}$ & $\begin{array}{c}\text { BB Sakti } \\
\text { GT 90 }\end{array}$ & $\begin{array}{c}\text { B Rejeki } \\
\text { GT 101 }\end{array}$ \\
\hline 4.8 & 10.15 & 14.61 & 15.77 & 17.48 & 18.63 & 19.15 \\
5.4 & 14.45 & 20.81 & 22.45 & 24.89 & 26.53 & 27.27 \\
6 & 19.83 & 28.54 & 30.80 & 34.14 & 36.39 & 37.42 \\
6.6 & 26.39 & 37.99 & 40.98 & 45.44 & 48.44 & 49.80 \\
7.2 & 34.26 & 49.32 & 53.21 & 59.00 & 62.88 & 64.65
\end{tabular}

Sumber : Data olahan, 2009 
Kapal dengan ukuran lebih besar akan membutuhkan bahan bakar lebih banyak untuk tiap mil jarak tempuhnya, dari grafik terlihat bahwa kapal dengan GT 101 untuk jarak 1 mil dengan kecepatan 6 knots membutuhkan bahan bakar solar (diesel fuel oil) 6,24 liter, GT 91 : 6,06 liter, GT 80: 5,69 liter, GT 71 : 5,13 liter, GT 61 ; 4,74 liter dan yang paling irit adalah GT 45 yaitu hanya 3,30 liter per milnya.

\section{Analisa Ekonomi Operasional Kapal Ikan}

Analisa ekonomi yang dilakukan adalah untuk mengetahui perbandingan tiap-tiap kapal ikan Purse Seine dengan dimensi kapal yang berbeda namun memiliki mesin 300 HP (Nissan RD.8) dengan kecepatan dinas sama yaitu 6,00 knots. Biaya operasional yang dibutuhkan oleh masingmasing kapal dan hasil tangkap yang diperoleh dibandingkan, agar dapat diketahui nilai ekonomis dari pemakaian mesin induk yang sama dengan dimensi kapal berbeda dan yang paling menguntungkan bagi nelayan, khususnya nelayan di daerah Pekalongan.

Biaya Operasional terdiri dari dua bagian yaitu : Biaya tetap dan Biaya tidak tetap serta biaya finansial, dimana komponen biaya tersebut meliputi:

- $\quad$ Biaya tetap (fixed cost) :

o Gaji tiap melaut (maning cost) dengan sistem bagi hasil.

o Perbaikkan dan perawatan (mesin, jaring dan kapal)

o Pelumasan mesin induk dan genset (lubricating oil)

o Asuransi

o Administrasi

- $\quad$ Biaya tidak tetap (variable cost/voyage cost) :

o Bahan bakar minyak (fuel oil cost).

o Pelabuhan (biaya untuk tambat dan labuh).

o Bahan makanan (storage cost).

o Air Tawar (minum, mandi \& cuci, pendingin mesin(closed sirculation freshwater)).

o Es, Garam, Minyak Tanah.

- Biaya finansial (financial cost) :

o Penyusutan (depreciation).

o Ongkos eksploitasi (overhead cost).

Contoh perhitungan biaya operasional kapal Purse Seine Pekalongan, khusus untuk Modren I (45 GT), adalah :

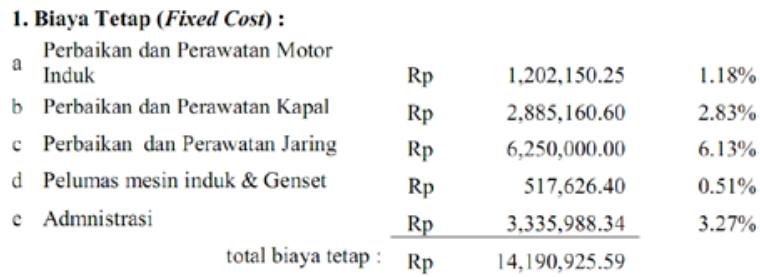

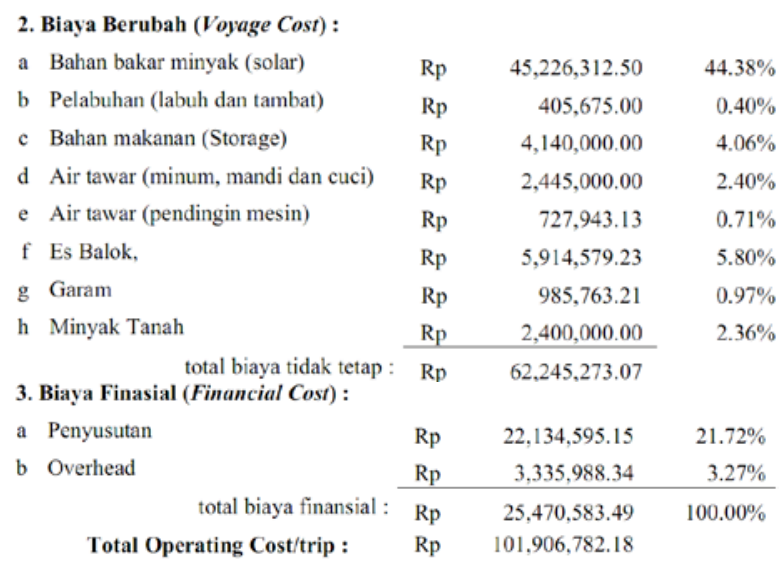

Biaya Operasional kapal ikan Modern I untuk per kg hasil tangkap;

$O C=\frac{\operatorname{Rp~} 101,906,782.18}{30.000 \mathrm{~kg}}=\quad R p .3,396,89 / \mathrm{kg}$

Uraian biaya operasional dapat dilihat dalam tabel 4.

Tabel 4. Biaya operasional 45 s/d 101 GT

\begin{tabular}{|c|c|c|c|c|c|c|}
\hline \multirow{3}{*}{ No. } & \multirow{3}{*}{ Nama Kapal } & \multirow{2}{*}{ GT } & \multicolumn{4}{|c|}{ Biaya Operasional kapal per Trip } \\
\hline & & & Tetap & Variabel & Finasial & Total OC \\
\hline & & tonnages & $\mathrm{Rp}$ & $\mathrm{Rp}$ & $\mathrm{Rp}$ & $\mathrm{Rp}$ \\
\hline 1 & 2 & 3 & 5 & 6 & 7 & 8 \\
\hline 1 & Modren I & 45 & $14,190,925.59$ & $62,245,273,07$ & $25,470,583.49$ & $101,906,782.16$ \\
\hline 2 & Cherly Prima Utame & 61 & $14,924,527.52$ & $84,445,921.93$ & $26,764,966.23$ & $126,135,415.68$ \\
\hline 3 & Yuie Jaya & 71 & $15,085,568.62$ & $89,388,216.54$ & $27,002,831.44$ & $131,476,616.60$ \\
\hline 4 & Bintang Mas Berlian & 81 & $15,634,913.86$ & $96,107,621,42$ & $28,063,875.55$ & $139,806,410.83$ \\
\hline 5 & Baruna Batare Sakti & 90 & $16,413,179.60$ & $102,743,454.18$ & $29,923,894.77$ & $149,080,528.55$ \\
\hline 6 & Bintang Rejeki & 101 & $18,628,609.96$ & $109,187,859,71$ & $35,650,522.65$ & $163,466,992.31$ \\
\hline
\end{tabular}

Hubungan antara ukuran kapal dengan besarnya biaya operasional melaut adalah:

$$
o C=a+b x+c x^{2}
$$

Dimana koeffisien data:

$$
\begin{array}{llll}
\mathrm{a}= & 49.583575 & \mathrm{~b}= & 1.282928 \\
\mathrm{c}= & -0.001729253 & \mathrm{x}= & \text { GT kapal }
\end{array}
$$

Distribusi biaya operasional untuk tiap item pembiayaan dimana 44\% merupakan biaya untuk bahan bakar minyak selama operasional melaut, 6\% biaya perawatan dan perbaikan jaring, 3\% untuk perawatan dan perbaikan kapal, 6\% Untuk es balok, dan garam, $22 \%$ penyusutan dan $3 \%$ overhead dan sisanya untuk bahan makanan selama melaut.

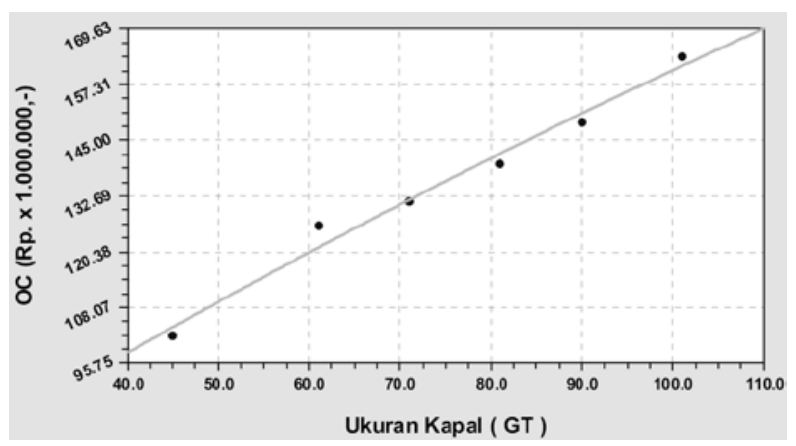

Gambar 4.Biaya operasional degan GT kapal 


\section{Perbandingan OC Per GT Kapal}

Perbedaan besar Biaya Operasional per trip (operation cost, OC) untuk pemakaian mesin induk yang sama (300 HP) pada kapal dengan ukuran berbeda per kg hasil tangkap yang akan di peroleh saat melaut dapat dilihat dalam grafik berikut.

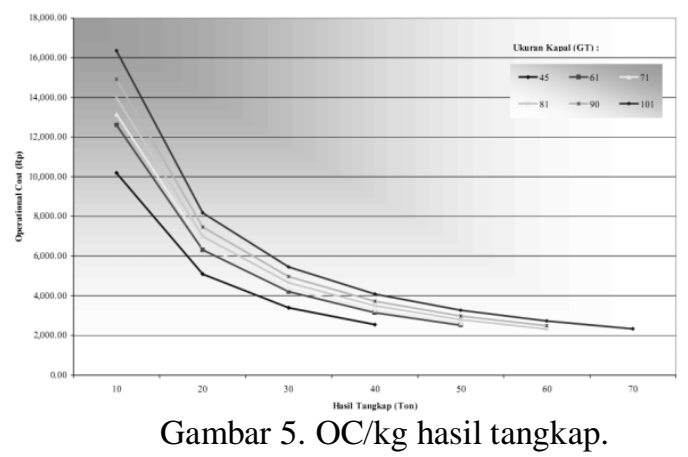

\section{Perbandingan Keuntungan Per GT Kapal}

Keuntungan yang diperoleh untuk masingmasing kapal dengan nilai atau harga ikan rata-rata :Rp. 4.914,-/kg, minimal Rp.3.266,-/kg dan maksimum Rp.6.542,-/kg di pelelangan ikan PPN Pekalongan (pada januari - Agustus 2009), sehingga hasil tangkapan ikan akan menghasilkan keuntungan, sebagai berikut :

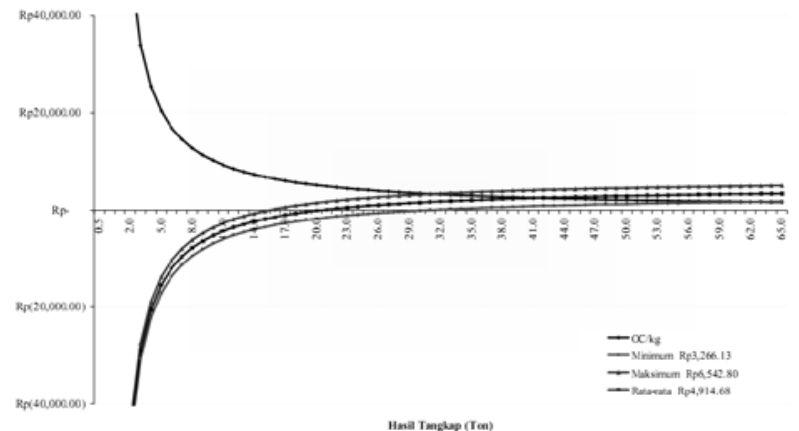

Gambar 6.Keuntungan dengan biaya operasional $(O C)$. Modern I

Keuntungan yang diperoleh jika hasil tangkap 36 ton adalah : minimal 15,38\%, maksimal 131,13\% dan rata-rata 73,62 \% untuk Modern I (45GT).

Tabel 5. Keuntungan purse seine Pekalongan

\begin{tabular}{|c|c|c|c|c|c|c|c|c|}
\hline \multirow{3}{*}{ No. } & \multirow{3}{*}{ Nama Kapal } & \multirow{2}{*}{ GT } & \multicolumn{3}{|c|}{ Triki ingas } & \multicolumn{3}{|c|}{ Persentas: Keunturgan } \\
\hline & & & \multicolumn{3}{|c|}{ Hasil Tangkap (Toa) } & \multicolumn{3}{|c|}{ Hasil Tanglap 36 Ton } \\
\hline & & (imamgs) & Mainsm & Mesimun & mana & \begin{tabular}{l|l} 
Mimimin \\
\end{tabular} & \begin{tabular}{l|l} 
Masimun & \\
\end{tabular} & trang \\
\hline 1 & 2 & 3 & 4 & 5 & 6 & 7 & 8 & 9 \\
\hline 1 & Modren ! & $45 \mathrm{GT}$ & 31.20 & 15.58 & 20.74 & $1533 \%$ & $131.13 \%$ & $73.62 \%$ \\
\hline 2 & Cherly Prima Utama & $61 \mathrm{GT}$ & 38.62 & 19.28 & 25.67 & $-6.78 \%$ & 86.748 & $40.27 \%$ \\
\hline 3 & Yuies Jaya & $71 \mathrm{GT}$ & 4025 & 20.09 & 26.75 & . $1057 \%$ & $79.15 \%$ & $34.57 \%$ \\
\hline 4 & Bintang Mas Berlin & $81 \mathrm{GT}$ & 4280 & 21.37 & 28.45 & . $15.90 \%$ & $68.48 \%$ & $26.55 \%$ \\
\hline 5 & Baruara Batara Sằiti & $90 \mathrm{GT}$ & 45.64 & 22.79 & 30.33 & $-21.13 \%$ & $58.00 \%$ & $18.68 \%$ \\
\hline 6 & Bintang Rejki & $101 \mathrm{GI}$ & 50.05 & 24.98 & 33.26 & $.2807 \%$ & $4.09 \%$ & $8.23 \%$ \\
\hline
\end{tabular}

Untuk kapal dengan ukuran 61 GT s/d 101 GT pada hasil penangkapan awal 36 ton rate keuntungan masih berada di bawah keuntungan 45 GT antara lain : -6,78\% (61 GT), -10,57\% (71 GT), 15,9\% (80 GT), -21,13\% (91 GT) dan 28,07\% (101 GT). Rate keuntungan ini di peroleh pada harga ikan minimal Rp.3.266,-/kg.

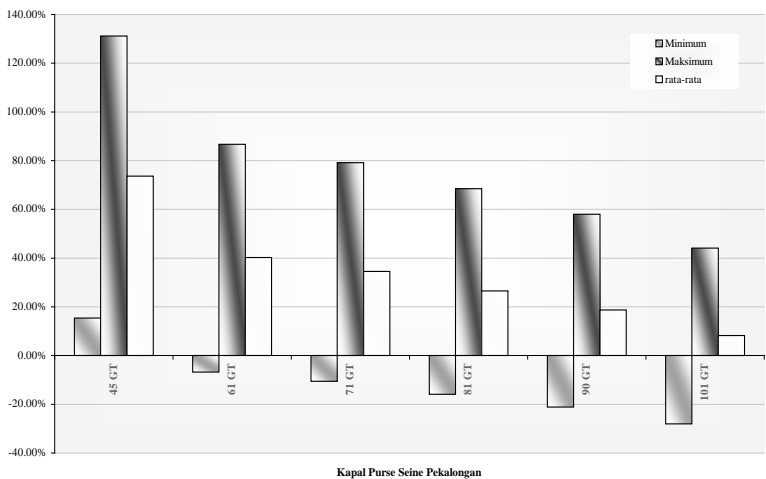

Gambar 7. Keuntungan kapal 45-101 GT, patokan 36 ton tangkapan.

\section{KESIMPULAN DAN SARAN \\ Kesimpulan}

Dalam penelitian ini mengambil 6 (enam) sampel kapal purse seine dengan ukuran kapal : 45 GT, 61 GT, 71 GT, 80 GT, 91GT dan 101 GT dan lokasi penelitian di PPN Pekalongan, dengan periode melaut 3 sampai 5 kali setahun, dari hasil survey dan pengolahan data lapangan diperoleh kesimpulan sebagai berikut :

- Konsumsi bahan bakar kapal dengan ukuran lebih besar akan membutuhkan bahan bakar lebih banyak untuk tiap mil jarak tempuhnya, dari grafik terlihat bahwa kapal dengan GT 101 untuk jarak 1 mil dengan kecepatan 6 knots membutuhkan bahan bakar solar (diesel fuel oil) 6,24 liter, GT 91 : 6,06 liter, GT 80: 5,69 liter, GT 71 : 5,13 liter, GT 61 ; 4,74 liter dan yang paling irit adalah GT 45 yaitu hanya 3,30 liter per milnya

- Biaya operasional penangkapan ikan terendah adalah untuk ukuran kapal 45GT = Rp.101.906.782,16/trip; tertinggi 101GT = Rp.163.466.992,31/trip. Biaya operasional (OC) yang paling ekonomis adalah kapal dengan ukuran 45 GT (Modern I). Biaya operasional yang mendominasi adalah penyediaan bahan bakar (solar ) $44 \%$.

- Tingkat keuntungan (profit rate) yang diperoleh kapal dengan ukuran 45 GT (ModernI) memiliki tingkat keuntungan diatas 15\% tertinggi di bandingkan dengan kapal dengan ukuran diatasnya.

\section{Saran}

Untuk ukuran kapal 61 GT s/d 101 GT menggunakan mesin induk dengan daya 300 HP efisiensi daya mesin lebih dari 100\% untuk mencapai kecepatan kapal 10.15 knots, sehingga perlu diganti dengan mesin induk yang memiliki daya lebih besar yaitu : 321,07 HP sampai 385 HP. 


\section{DAFTAR PUSTAKA}

1. Ayodhyoa, AU, 1976, Teknik Penangkapan Ikan. Bagian Teknik Penangkapan Ikan. IPB, Bogor.

2. Beever, C, 1979 Fishing Boat of The World : Economic Influence Design Of Fishing Craft, FAO, Fishing News Book Ltd, England.

3. Departemen Kelautan dan Perikanan, JICA, 2009, Text book Pengelolaan Sumber Daya Perikanan, DKP, Jakarta

4. Fyson,John, 1985. Design of Small Fishing Vessel, FAO-UN, Fishing News Book Ltd, England.

5. Harvald,S A, 1992, Tahanan dan Propulsi Kapal, Airlangga University Press, Surabaya.

6. Kepas, 1987, Perubahan dan Pengelolaan Kawasan Pantai Utara Jawa, departemen Pertanian, Jakarta.

7. Lewis, Edward V, 1988, Principle of Naval Architecture Second Edition, the Soeciety of Naval Architecture and Marine Engineers, New Jersey.

8. MAN B\&W, 2002, Basic Principles of Ship Propulsion, Germany.

9. Muhammad, 2002, Penentuan Status Sumberdaya Perikanan Jawa Timur, Fakultas Perikanan, Unibraw, Malang

10. Muntaha, 2003, Pengaruh Kecepatan Kapal Terhadap Hasil Tangkap Ikan dengan Alat
Tangkap Purse Seine di Perairan Probolinggo, ITS, Surabaya.

11. Nomura, M Yamazaki, 1977, Fishing Technic (1) Japan International Corperation Agency, Tokyo.

12. Pounder's, 2004, Marine Diesel Engines and Gas Turbines, Eighth edition, Butterworth, Amsterdam Boston.

13. Riyanto, 1989, Dasar-Dasar Pembelanjaan, Yayasan Penerbit UGM, Yogyakarta.

14. Soeharjo, M. 1982, Azas-Azas Akuntansi, suatu Pengantar, FE UGM, Yogyakarta.

15. Sudjana, 1996, Metode Statistika, edisi ke 6, Tarsito, Bandung

16. Soekartawi, 1990, Teori Ekonomi Produksi, dengan Pokok Bahasan Analisis Fungsi Cobb Douglas, Rajawali Perss, Jakarta.

17. Sudirman, Mallawa Achmad, 2004, Teknik Penangkapan Ikan, Reneka Cipta, Jakarta.

18. San Fransisco Maritime Association, 2004, Diesel Engine Fuel Systems A. Diesel Fuels, Maritime Park Association.

19. Yahya, 2001, Perikanan Tangkap Indonesia, Fakultas Perikanan dan Ilmu Kelautan, IPB, Bogor. 